\title{
Percepção geográfica e planejamento turístico: um estudo sobre a Sazonalidade
}

\section{Geographical perception and tourism planning: a Seasonality study}

\author{
Luciane Scheuer (SCHEUER, L.) ${ }^{*}$
}

\begin{abstract}
RESUMO - Neste artigo se traz uma reflexão teórico-descritiva sobre sazonalidade do turismo e para tanto são tecidas considerações sobre o fenômeno turístico, seu planejamento e questões ligadas à percepção geográfica do turismo, focando algumas situações relacionadas ao município de Guaratuba (Paraná, Brasil). O turismo está em constante expansão no Brasil, mas percebe-se que seu crescimento na maioria das vezes é desordenado e com objetivos de curto prazo. Para reverter os impactos negativos da sazonalidade, principalmente em balneários de veraneio, muito ainda deve ser feito, começando por estudos que levantem dados e analisem as situações dos municípios que passam por tais problemas, voltando seus resultados para o planejamento da atividade. Guaratuba sofre anualmente com os efeitos advindos da sazonalidade principalmente econômicos e sociais. Utilizando pesquisa exploratória e observação assistemática obteve-se como resultado uma análise preliminar sobre a sazonalidade no município, percebendo-se, dessa forma, a necessidade de conhecer o seu território e saber pensar o espaço para o desenvolvimento da atividade turística ordenada.
\end{abstract}

Palavras-chave: Turismo; Sazonalidade; Planejamento; Guaratuba.

ABSTRACT - This paper provides a theoretical and descriptive reflection about tourism seasonality and for that are concerned considerations on the phenomenon of tourism, its planning and issues related to tourism geographical perception, focusing on some situations related to Guaratuba (Paraná, Brazil). Tourism is steadily expanding in Brazil, but it is clear that its growth is mostly disordered and with short-term goals. To reverse the negative impacts of seasonality, particularly in summer watering places, much still needs to be done, starting with studies that raise data and analyze the situations of some cities that experience such problems, returning their results to the tourism activity planning. Guaratuba suffers annually with the effects from seasonality, mainly in its economy and in its social terms. Using exploratory research and systematic observation was obtained as a result a small analysis on the seasonality and its impacts to the city, realizing thus, the need to know its territory and how to think the space for the orderly development of tourism.

Key words: Tourism; Seasonality; Planning; Guaratuba.

\footnotetext{
* Graduação em Turismo pela Universidade Federal do Paraná (UFPR) e em Comunicação Social pela Pontifícia Universidade Católica do Paraná (PUC-PR). Especialização em Planejamento e Gestão do Turismo (UFPR) e em Gestão Empresarial pela Faculdade Mater Dei (Pato Branco, Paraná). Mestre e Doutoranda em Geografia (UFPR). Professora do curso de Turismo do Instituto Superior do Litoral do Paraná (ISULPAR) em Paranaguá (PR) e Professora do Curso de Administração do Instituto Superior de Pesquisa em Extensão (ISEPE) em Guaratuba (PR). Endereço: Av. Curitiba, 360, ap. 201. CEP: 83280000 - Guaratuba - PR (Brasil). Telefone: (41) 8835-0476. E-mail: luscheuer@ hotmail.com
} 


\section{INTRODUÇÃO}

Neste artigo se buscou abordar algumas teorias inerentes ao turismo em geral e voltá-las para o estudo do turismo sazonal, com a intenção de identificar os impactos econômicos, sociais, ambientais, políticos e administrativos dele decorrentes. $\mathrm{O}$ município de Guaratuba, litoral do estado do Paraná (Brasil) também sofre tais impactos e com isso necessita de planejamento constante, a fim de tentar reverter à situação da sazonalidade, fazendo com que o turismo possa ser explorado satisfatoriamente o ano todo. Os prejuízos do turismo sazonal em muitos balneários são muito maiores do que o retorno que ele provém em épocas de temporada. Basta uma temporada ruim, com mau tempo, ou problemas na economia nacional, que o local demorará anos para se recompor.

Butler (1994, p. 332) define o turismo sazonal como "um desequilíbrio temporal no fenômeno turístico, que pode ser expresso em termos de dimensões tais como: número de visitantes, despesas de visitantes, tráfego nas autoestradas e outras formas de transporte, emprego e ingressos em atrações." Portanto, pode-se considerar que a sazonalidade é a concentração dos fluxos turísticos em períodos curtos do ano, promovendo picos de atividades relacionadas ao turismo.

A ideia desse estudo também se direciona em estabelecer conexões entre o fenômeno turístico e a sua percepção geográfica, bem como, mostrar algumas peculiaridades do turismo em Guaratuba, como a sazonalidade torna-se impactante para a comunidade local, bem como ressaltar a importância do planejamento turístico. Podese antecipar que municípios que possuem balneários como Guaratuba, devem buscar constantemente outras formas de atrair turistas além de sol e mar, melhorar a qualidade dos serviços prestados e da infraestrutura turística fora da temporada de verão. $\mathrm{O}$ turismo guaratubano é essencialmente de veraneio e isso ocasiona grandes dificuldades em manter as atividades e a receita da cidade fora dessa época.

Pode-se considerar que trabalhos como estes sejam de grande relevância para o desenvolvimento de outros estudos sobre turismo de modo geral e para a geografia em particular, pois este leva em consideração alguns aspectos geográficos de ordem territorial, espacial, econômica, entre outros, tanto para as pessoas interessadas neste assunto e principalmente para o município de Guaratuba, que anualmente sofre com os efeitos decorrentes da sazonalidade. Percebe-se dessa forma que lugares que convivem 
com a sazonalidade devem procurar desenvolver estratégias para enfrentá-la, para minimizarem as situações de altos e baixos fluxos.

Quanto à metodologia, este trabalho pode ser considerado um estudo exploratório e descritivo de ordem bibliográfica e documental e também de observação assistemática, que "é uma técnica não estruturada, também podendo ser denominada de espontânea, simples e livre, que consiste em recolher e registrar os fatos da realidade sem que o pesquisador utilize meios técnicos específicos ou precise fazer perguntas diretas" (MARCONI e LAKATOS, 2008), já que muitas situações foram levantadas através da observação direta da autora.

Este artigo foi desenvolvido inicialmente junto à disciplina de Produção Turística e seus efeitos sociais, econômicos e culturais no espaço urbano e regional do Programa de Pós-Graduação de Mestrado e Doutorado em Geografia da Universidade Federal do Paraná (UFPR), tendo a sua versão preliminar sido apresentada no VI Seminário da Associação Brasileira de Pesquisa e Pós-Graduação em Turismo ANPTUR - 2008 realizado na cidade de Belo Horizonte (Minas Gerais). Posteriormente serviu de base para a elaboração da dissertação de mestrado intitulada Sazonalidade do Turismo no Município de Guaratuba - PR.

Portanto, neste artigo se abordou os conceitos relacionados ao turismo e à sua percepção geográfica num primeiro instante, procurando voltá-los para o estudo do planejamento turístico e do turismo sazonal no município de Guaratuba, litoral do Estado do Paraná.

\section{CONCEITOS DE TURISMO}

A sociedade humana, tão sedentária até recentemente, pôs-se em movimento, com isso, a grande mobilidade tomou conta da maioria dos habitantes das nações industriais. Se busca aproveitar todas as oportunidades para viajar, oportunidades de fugir do cotidiano, com a maior frequência possível, pois não há desejo maior que o de viajar, mudar de endereço e é por isso que é tão importante e complexo o estudo da atividade turística. (KRIPPENDORF, 1989).

Por ser um tema complexo e em ampla expansão, há tantas definições, quanto autores, escrevendo sobre o mesmo. Para Barretto (1991, p. 47-48), o turismo é 
“essencialmente o movimento de pessoas e de atendimento às suas necessidades, assim como às necessidades das outras pessoas que não viajam. O turismo é o fenômeno de interação entre o turista e o núcleo receptor e de todas as atividades decorrentes dessa interação".

Acompanhando as mudanças globais em curso, a OMT (2001, p. 38) propõe a seguinte definição: o turismo compreende as atividades realizadas pelas pessoas durante suas viagens e estadas em lugares diferentes do seu entorno habitual, por um período consecutivo inferior a um ano, por lazer, negócios ou outros.

Vale salientar também outra conceituação a partir de Silveira (2002) que define o Turismo como:

[...] atividade que consiste no deslocamento de pessoas, provisório e limitado no tempo e no espaço, de tal modo que não implica na transferência do local habitual de residência, que possui motivações diversas (que podem ir do simples lazer, passando pela curiosidade, educação, saúde, cultural, aventura, indo até aspectos de ordem profissional e religiosa), e que tem, por um lado, como subjacente ao aproveitamento desse tempo de deslocamento, um desejo de evasão por parte do ser humano do seu território cotidiano e, por outro lado, a busca por novos espaços e culturas de forma mais ou menos vinculada, e que não deixará de produzir efeitos de ordem econômica, social, cultural e ambiental. Portanto, entende-se o Turismo como uma atividade que também produz e consome espaços, sendo responsável por novas territorialidades [...] (SILVEIRA, 2002, p. 21).

Pode-se estipular, dessa forma, que o turismo é uma atividade multidisciplinar que, em sua amplitude, não está formada só pelas pessoas que viajam e pelos bens e serviços oferecidos e utilizados, mas que entre uns e outros surge uma série de relações e situações de caráter econômico, sociológico, geográfico e até mesmo político.

Bahl (2004, p. 45), acrescenta que em sua essência, o turismo pode ser um promotor das localidades onde ocorre, obrigando a necessidade do resgate da cultura local, o estímulo à autoestima e valorização dos hábitos e costumes autóctones. O mesmo autor salienta que a manutenção da autenticidade das localidades é um dos recursos mais promissores do turismo.

Vislumbrando pelo lado da localidade receptora, o turismo é capaz de produzir impactos consideráveis na economia de um local. Para Oliveira (2005), é um meio de redistribuir a renda, captar divisas, gerar novos empregos, incrementar outros setores econômicos, aumentar a arrecadação fiscal, promover o desenvolvimento regional e motivar novos investimentos com benefícios sociais. 
De acordo com Beni (1998, p. 41) o turismo é uma atividade realmente ampla e que pode ser considerado um eficiente meio para: 1) Promover a difusão de informação sobre uma determinada região ou localidade, seus valores naturais, culturais e sociais; 2) Abrir novas perspectivas sociais como resultado do desenvolvimento econômico e cultural de uma região; 3) Integrar socialmente, incrementar (em determinados casos) a consciência nacional; 4) Desenvolver a criatividade em vários campos; 5) Promover o sentimento de liberdade mediante a abertura ao mundo, estabelecendo ou estendendo os contatos culturais, estimulando o interesse pelas viagens turísticas.

Mas como atividade econômica, o turismo também pode provocar danos e prejuízos ao meio visitado, para Beni (1998, p. 41), os prejuízos seriam os seguintes: 1) Degradação e destruição dos recursos naturais; 2) Perda da autenticidade da cultura local; 3) Descrição estereotipada e falsa do turista e do país ou região de que procede, por falta de informação adequada; 4) Ausência de perspectivas para aqueles grupos da população local das áreas de destinação turística, que não obtêm benefícios diretos das visitas dos turistas ou do próprio Sistema de Turismo da localidade; 5) Aparecimento de fenômenos de disfunção social na família, patologia no processo de socialização, desintegração da comunidade; 6) Dependência do capital estrangeiro ou de estereótipos existentes em face do turismo.

Por tudo isto que foi descrito anteriormente, a conceituação de turismo não pode ficar limitada a uma simples definição, pois este é um fenômeno que ocorre em distintos campos de estudo, em que é explicado conforme diferentes correntes de pensamento, e verificado em contextos vários da realidade social. Cada lugar possui sua identidade pelas características de sua geografia física, aliadas às suas características culturais, econômicas, sociais, políticas, entre outras.

Portanto, Oliveira (2005), define o turismo de forma a contemplar os diferentes aspectos em que ele está inserido. Seu conceito traz o seguinte:

\footnotetext{
Dá-se o nome de turismo à atividade humana que é capaz de produzir resultados de caráter econômico financeiro, político, social e cultural produzidos numa localidade, decorrentes do relacionamento entre os visitantes com os locais visitados durante a presença temporária de pessoas que se deslocam de seu local habitual de residência para outros, de forma espontânea sem fins lucrativos. (OLIVEIRA, 2005, p. 36).
}

Portanto, através do comentado a partir de Oliveira (2005), consegue-se perceber a amplitude, a complexidade e multidisciplinaridade do fenômeno turístico. 
Mas junto com a atividade turística há a sazonalidade e seus impactos às comunidades receptoras. O turismo planejado e ordenado de forma adequada pode auxiliar tais comunidades a minimizar os impactos negativos advindos do turismo sazonal. Ter a percepção geográfica do fenômeno turístico e compreender o espaço geográfico onde o turismo acontece, suas características, suas relações sociais, seus valores, enfim, o ambiente onde está inserido, pode auxiliar no entendimento da atividade e seus impactos nesse espaço.

\section{A PERCEPÇÃo GEOGRÁFICA DO FENÔMENO TURÍSTICO}

Como em outras linhas de pensamento, na Geografia também se encontram formas de interpretar o fenômeno turístico, tão crescente na sociedade contemporânea. Além de envolver fatores da geografia física, o turismo interfere em questões econômicas e sociais, oferecendo à Geografia grandes possibilidades de estudos sobre lugar, valores e atitudes.

Para Xavier (2001), os estudos sobre a percepção geográfica do turismo, como uma das alternativas de abordagem em Geografia, desenvolveram-se devido à preocupação no sentido de conhecer e de explicar as atitudes e os valores da população frente ao meio ambiente.

Para uma compreensão mais atinente de espaço geográfico pode-se citar Santos (2004, p. 153), que afirma o seguinte: “o espaço se define como um conjunto de formas representativas de relações sociais do passado e do presente e por uma estrutura representada por relações sociais que estão acontecendo diante dos nossos olhos e que se manifestam através de processos e funções". O espaço é, então, um verdadeiro campo de forças cuja aceleração é desigual. Daí porque, a evolução espacial não se faz de forma idêntica em todos os lugares.

Percebe-se através das palavras de Santos, que o conhecimento do espaço, de seus objetos e de sua movimentação permite sua compreensão e seu estudo, conseguindo melhor conhecer o meio ambiente e apreender formas de ação para seu uso, sua valorização e, quando necessário, para assumir atitudes em relação a ele. É assim que se integra o homem em seu meio ambiente. 
O espaço geográfico é o principal objeto de consumo do turismo e disso decorre uma das mais importantes especificidades da prática social do turismo: o turista tem de se deslocar até o produto a ser consumido, o lugar turístico. (Boullón, 1997). Em função dessa característica, o turismo acaba por causar transformações, diretamente ao menos em três porções do espaço geográfico, que segundo Cruz (2001) são: os polos emissores de fluxos, os espaços de deslocamento e os núcleos receptores.

A percepção geográfica do turismo torna-se bastante complexa, já que envolve vários segmentos da atividade humana atingindo diversificados grupos de pessoas, tais como: políticos, planejadores, diferentes tipos de profissionais, turistas e o mais importante, a comunidade receptora. Segundo Xavier (2001), a preocupação da geografia, além de recair sobre a percepção de todas as pessoas envolvidas com o turismo se acentua sobre a percepção dos moradores locais. Nota-se que a percepção dessas pessoas é influenciada por inúmeros fatores, tais como a possibilidade de trabalho, a renda, o conforto, a perda de privacidade, além do fato de ver seus bens de uso se transformando em verdadeiras mercadorias à disposição dos visitantes. Sendo a percepção individual e seletiva dos moradores, a resposta dos seus sentimentos em relação ao turismo, que pode ser alterada na medida em que a implantação do turismo local vai adquirindo maiores proporções.

O conhecimento da percepção geográfica do turismo em bases locais poderá exercer, também, grande contribuição no desenvolvimento de uma conduta do homem, no sentido de que a atividade turística possa se estabelecer visando uma melhor qualidade de vida da população. É necessário pensar o espaço para serem desenvolvidas atividades turísticas planejadas e possivelmente ter condições de melhorar os núcleos receptores a fim de contribuir para um desenvolvimento econômico, social e ambiente mais homogêneo.

\section{PLANEJAMENTO TURÍSTICO}

O turismo é um fenômeno em expansão no mundo. A receita gerada pelo turismo internacional tem se equiparado a setores tradicionais como o do petróleo, dos automóveis e dos equipamentos eletrônicos. (MAMBERTI; BRAGA, 2004). 
Segundo Portuguez (2002), a atividade representa acentuada fonte de geração de renda, de empregos, e de divisas para vários países. Por isso, o turismo tem sido frequentemente apontado como uma "saída estratégica" para o desenvolvimento, sendo incentivado pelos governos, desejado pelos empresários, procurado pelos consumidores e ainda podendo ser considerado uma oportunidade de crescimento para os núcleos receptores, sobretudo os economicamente deprimidos.

Diante da grande potencialidade do turismo em gerar riquezas, se contrapõem vários impactos negativos que podem surgir com o seu crescimento. O turismo não deve ser visto como uma alternativa "milagrosa" com resultados econômicos de curto prazo, mas sim como uma atividade que deve ser planejada e monitorada constantemente com o objetivo de trazer satisfação aos turistas e dignidade à população autóctone. Às vezes, o desenvolvimento da atividade pode ter resultados catastróficos nas localidades receptoras, decorrentes da ausência ou de um mau planejamento turístico ou da falta de avaliação dos resultados de sua implantação.

Para Ackoff (1975, p. 25) "planejamento é um processo que se destina a produzir um ou mais estados futuros desejados e que não deverão ocorrer a menos que alguma coisa seja feita". Para o desenvolvimento do turismo em qualquer localidade, o planejamento adequado e ordenado torna-se essencial. É importante lembrar que, “o planejamento é uma atividade, não algo estático, é um devir, um acontecer de muitos fatores concomitantes que têm que ser coordenados para se alcançar um objetivo que está em outro tempo". (BARRETO, 1991, p. 12). Sendo algo dinâmico e que necessita permanente revisão, correção do seu rumo, exigindo um repensar constante.

Um planejador não pode trabalhar na base do empírico, "vamos fazer e ver no que vai dar", antes é preciso um estudo aprofundado de todo o contexto presente, da conjuntura socioeconômica em que o planejamento está inserido, assim como do próprio planejador. Então, resumidamente, um planejamento consiste na definição dos objetivos, na ordenação dos recursos, na determinação dos métodos e formas de organização, no estabelecimento das medidas de tempo, na localização espacial, entre outros aspectos. Para Barretto (1991), o planejamento requer compreensão dos problemas e distribuição harmônica das especialidades, requer conhecimento.

Planejar é auxiliar a visão de um futuro próximo ou distante, o que contribui para que tarefas sejam melhor realizadas e objetivos sejam mais facilmente atingidos 
por pessoas ou organizações. Conforme Petrocchi (1998, p. 20), o planejamento "ordena as ações e dá prioridade a elas, permite mapear dificuldades ou obstáculos e, assim, escolher previamente caminhos alternativos".

Pode-se considerar que planejar turismo é planejar um território e para isso torna-se necessário conhecê-lo, e conhecê-lo muito bem. As estratégias de planejamento turístico estão intimamente ligadas às informações que o planejador tem em mãos. Sem conhecer a localidade e sua realidade o planejamento perde seu foco $\mathrm{e}$ consequentemente não atinge os seus objetivos. Diante disso nota-se que um território não é simplesmente um espaço onde um grupo se reúne, mas também um instrumento de ordem social.

Levando-se em consideração o que foi mencionado anteriormente, surge a seguinte argumentação a partir de Luchiari (1999, p. 59):

\footnotetext{
Que a organização territorial dos lugares turísticos e sua exploração mercantil não responde somente à lógica do lugar, do meio, e da população local: ela é a reprodução de atributos valorizados nos centros urbanos emissores, sintetizando a materialidade das cidades que se expandem, as novas representações sociais impressas ao uso do território e tudo que é planejado sobre ele.
}

A partir dessa consideração, percebe-se a importância do planejamento atrelado ao estudo da oferta em comum acordo com os objetivos da demanda. Nenhum bom trabalho relativo à oferta terá valor ou retorno se não trabalhar intimamente ligado à realização dos desejos e ansiedades da demanda. Torna-se difícil prever qualquer situação futura sem conhecer o que a localidade tem a oferecer e quais são as reais necessidades do público que ela pretende atender.

Mas planejamento e/ou crescimento do turismo deve estar atrelado ao consentimento governamental. As políticas de turismo primam pela parceira entre o poder público e o privado e os profissionais capacitados para exercerem o papel de planejadores. Um bom plano de desenvolvimento do turismo somente será viável com a consolidação de algumas vertentes, sendo elas: o governo, a comunidade local, os investidores e o espaço onde o turismo estará inserido. A elaboração de diagnósticos aprofundados, a procura por novas parcerias e a postura de compromisso com o desenvolvimento local são exigências para uma atuação eficaz do poder público local (DOWBOR, 1996). 
Krippendorf (1989, p. 24) argumenta que "devemos, antes de mais nada, dominar o funcionamento do mecanismo, antes que possamos determinar os meios de controlá-lo, modificá-lo e aperfeiçoá-lo”. Ou seja, planejar o turismo, pois tudo que é planejado é mais organizado e traz melhores resultados.

Turismo ordenado, sustentável e capaz de atrair turistas e renda à comunidade de um local é o turismo planejado em comum acordo com políticas governamentais visando a qualidade de vida da população local e a qualidade nos serviços prestados aos visitantes, dessa forma contribuindo significativamente para a diminuição dos impactos causados pelo turismo sazonal.

\section{SAZONALIDADE DO TURISMO E SEUS IMPACTOS}

A sazonalidade, em seu sentido contextual, pode ser definida "como um determinado período para a ocorrência de um fenômeno, ou seja, aquele que ocorre em alguns períodos e em outros não.” (MOTA, 2001, p. 98). Para Ruschmann (1995), a sazonalidade turística é decorrente da concentração das atividades turísticas no espaço e no tempo.

Muitos fatores podem condicionar a demanda turística, segundo Dencker (1998), estes podem ser: fatores demográficos, fatores sociológicos, fatores econômicos, fatores turísticos e a sazonalidade. A sazonalidade da demanda turística considera as seguintes variáveis: férias escolares ou dos trabalhadores, poder aquisitivo, concentração espaçotemporal. (MOTA, 2001).

Independentemente da variável, a ocorrência da sazonalidade turística, conforme Mota (2001, p. 98) produz consequências em diversos níveis: gera desemprego, mortalidade em microempresas, queda no faturamento de empresas turísticas, alteração no sistema de gestão, compromete a qualidade no atendimento, modifica a política promocional do produto turístico, altera preços, exige maior flexibilidade administrativa, entre outros fatores.

Acentua-se a quantidade de pesquisas que tentam estudar os impactos do turismo sobre a economia, o meio ambiente e a população em áreas de grande sazonalidade. $\mathrm{O}$ turismo sazonal é algo complexo, amplo e difícil de ser explicado. Por que existe a sazonalidade? Os núcleos receptores estão preparados para três ou quatro meses de 
trabalho intensivo, e o resto do ano, o que fazer? Esses impactos são muito danosos, pois os nativos trabalham em excesso para receber o turista por três ou quatro meses e durante o resto do ano ficam praticamente ociosos.

A sazonalidade traz com ela os problemas sociais, culturais, ambientais, administrativos e principalmente econômicos. Segundo Moraes (2004), os territórios onde se desenvolve o turismo sazonal sofrem alterações significativas durante a temporada e têm suas paisagens em mutação permanente, como consequência de uma procura em atender às supostas necessidades do turista. Esses locais dificilmente possuem uma paisagem estática, as mudanças são constantes, sejam elas por motivos ambientais, econômicos, sociais ou culturais.

Os principais impactos da sazonalidade do turismo no município de Guaratuba, por exemplo, seriam, principalmente, os econômicos, os sociais e os culturais. O município, durante três ou quatro meses no ano "respira" turismo, a sua renda é altamente influenciada pela quantidade de turistas que nele permanecem durante dias de verão. Mas em contrapartida, no inverno, a população, em poucos meses acaba com a renda que lhe foi auferida na temporada, tendo dificuldades em ter uma renda fixa durante o resto do ano. A partir desse problema econômico, surgem os problemas sociais, tais como: a criminalidade, a fome, o desemprego, dentre outros. O maior impacto na sazonalidade não está no investidor ou no empresário que aproveita o verão para fazer seu caixa para o ano todo, mas, no caiçara, que gasta tudo que ganhou na temporada em poucos meses, e sem dinheiro para prover sua família procura outros meios para sobreviver.

Ball (1989) acrescenta que a sazonalidade da demanda é uma característica distinta do turismo, das atividades baseadas em lazer e em negócios associados. Isto acontece porque o foco da atividade são as férias de verão, um assunto que está ligado à variação temporal das atrações e recursos turísticos. O grau da sazonalidade que acontece em qualquer área depende da natureza das atrações turísticas. Áreas costeiras, portanto, possuem particularmente um "pico" de demanda em certas épocas do ano, porque são dependentes de uma estação tradicionalmente influenciada pelo clima. (BALL, 1989, p. 2) 
No quadro 1 se procura sintetizar os principais aspectos benéficos e maléficos decorrentes do desenvolvimento do turismo sazonal, considerando as suas diferentes esferas.

\begin{tabular}{|c|c|c|}
\hline ÁREA & $\begin{array}{l}\text { IMPACTOS POTENCIAIS } \\
\text { POSITIVOS }\end{array}$ & $\begin{array}{c}\text { IMPACTOS POTENCIAIS } \\
\text { NEGATIVOS }\end{array}$ \\
\hline Econômica & $\begin{array}{l}\text { Receitas, empregos, nível de vida da } \\
\text { população local, atração de } \\
\text { investimentos. }\end{array}$ & $\begin{array}{l}\text { Inflação local, especulação } \\
\text { imobiliária, concentração dos } \\
\text { investimentos e perda de } \\
\text { investimentos alternativos, custos em } \\
\text { termos de infraestruturas necessárias. }\end{array}$ \\
\hline Turismo e Comércio & $\begin{array}{l}\text { Reconhecimento da região, novas } \\
\text { infraestruturas, maior acessibilidade. }\end{array}$ & $\begin{array}{l}\text { Preços mais elevados, } \\
\text { Desenvolvimento descontrolado do } \\
\text { comércio local. }\end{array}$ \\
\hline Sociedade e Cultura & $\begin{array}{l}\text { Maior empenho dos residentes na } \\
\text { promoção dos eventos locais, reforço } \\
\text { dos valores e tradições locais. }\end{array}$ & $\begin{array}{l}\text { Comercialização sazonal de } \\
\text { atividades privadas, alteração dos } \\
\text { costumes em função do turismo, } \\
\text { custos sociais (prostituição, abuso de } \\
\text { drogas e álcool) }\end{array}$ \\
\hline Psicologia & $\begin{array}{l}\text { Orgulho quanto aos costumes } \\
\text { locais, reconhecimento da riqueza da } \\
\text { troca com o outro. }\end{array}$ & $\begin{array}{l}\text { Atitudes defensivas face à outras } \\
\text { culturas, hostilidades por dificuldade } \\
\text { de comunicação. }\end{array}$ \\
\hline $\begin{array}{c}\text { Política e } \\
\text { Administração }\end{array}$ & Desenvolvimento local integrado. & $\begin{array}{l}\text { Mau planejamento, segregação sócio- } \\
\text { espacial. }\end{array}$ \\
\hline Meio Ambiente & $\begin{array}{l}\text { Novas infraestruturas, conservação de } \\
\text { algumas áreas, estratégias de gestão } \\
\text { sustentável. }\end{array}$ & $\begin{array}{l}\text { Degradação ambiental, poluição, } \\
\text { alteração de hábitos alimentares, } \\
\text { produção excessiva e sazonal de } \\
\text { resíduos sólidos. }\end{array}$ \\
\hline
\end{tabular}

QUADRO 1 - ASPECTOS BENÉFICOS E MALÉFICOS DO TURISMO SAZONAL

FONTE: DROULERS E MILANI, 2002.

O turismo também precisa de mão-de-obra especializada para garantir a qualidade dos seus serviços e, caso a localidade turística não possua pessoal com a qualificação necessária, essas vagas são preenchidas por um mercado de trabalho externo. Uma localidade que pretende incentivar o desenvolvimento do turismo deve investir em qualificação profissional para a população local. E isso pode se tornar complicado em balneários sazonais, pois além da falta de qualificação das pessoas, falta o interesse dos nativos em melhorar sua capacitação, já que se tem trabalho apenas durante uma época do ano.

Percebe-se a partir daí a importância de um planejamento turístico constante que busque criar mecanismos efetivos para garantir a reversão dos malefícios advindos do desenvolvimento da atividade para as populações dos núcleos receptores. A não 
existência de políticas em relação ao desenvolvimento do turismo contribui para que as comunidades das localidades onde ele ocorra sejam alheias ao seu processo de desenvolvimento, embora sejam submetidas a todas as consequências, boas e ruins, provocadas pela atividade.

Quando a atividade turística é organizada de modo sistêmico e integrado os benefícios se expandem tanto para as empresas quanto para os turistas e a economia local. Para incentivar o turismo, fora da temporada de verão se faz imprescindível identificar a cadeia produtiva do turismo, que permite traçar um panorama da situação vigente. Esse levantamento possibilita dimensionar os impactos diretos e indiretos do setor do turismo na economia local e verificar se há ocorrência de efeitos multiplicadores que contribuam para a expansão de outras atividades econômicas internas.

Em consonância ao que foi abordado anteriormente, seguem algumas informações sobre a sazonalidade no município de Guaratuba.

\section{SAZONALIDADE DO TURISMO NO MUNICÍPIO DE GUARATUBA}

Como objeto de estudo desta pesquisa surge o município de Guaratuba, que sofre anualmente os impactos da sazonalidade. Para localizar geograficamente o objeto de estudo alguns dados, obtidos junto à Guaratuba, Prefeitura Municipal (2009), foram levados em consideração, ou seja, município está localizado a $3 \mathrm{~m}$ de altitude, possui área de $1.316,51 \mathrm{~km}^{2}$ e dista $115 \mathrm{~km}$ de Curitiba, capital do estado, $65 \mathrm{~km}$ de Joinville, em Santa Catarina, e $54 \mathrm{~km}$ da cidade de Paranaguá. Possui população de 32.013 habitantes, de acordo com informação do Instituto Brasileiro de Geografia e Estatística (IBGE, 2010), sendo $86 \%$ na área urbana e $14 \%$ na área rural, conforme consta no documento Domicílios e População, Censo 2010. Seu clima é tropical super-úmido, sem estação seca definida, com temperatura média de $22^{\circ} \mathrm{C}$ no verão e $18^{\circ} \mathrm{C}$ no inverno, de acordo com o Caderno Estatístico do Município de Guaratuba (IPARDES, 2009) e sua latitude é $25^{\circ} 52^{\prime}$ 58" Sul e sua longitude é $48^{\circ} 34^{\prime}$ 29" Oeste, segundo o mesmo documento. Na figura 1 identifica-se que limita-se ao norte com os municípios de Morretes e Paranaguá e a leste com o município de Matinhos e Oceano Atlântico. Ao 
sul faz divisa com os municípios de Itapoá e Garuva no estado de Santa Catarina e a oeste com o município de São José dos Pinhais.

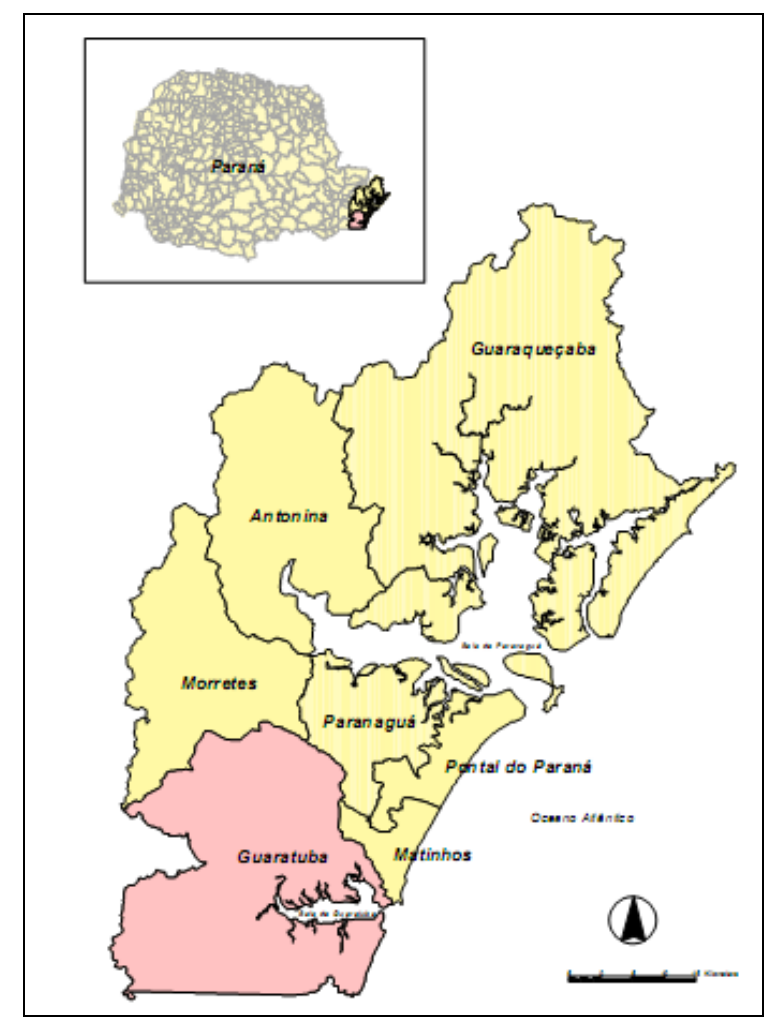

FIGURA 1 - CARTOGRAMA DE LOCALIZAÇÃO DO MUNICÍPIO.

FONTE: Conselho do Litoral (2002, p. 18).

O município é essencialmente turístico e seus principais atrativos são: a Praia de Caieiras, a Praia Prosdócimo, a Praia Central, a Praia de Brejatuba, o Morro do Cristo, o Salto Parati, a Baía de Guaratuba (local de esportes náuticos e pesca esportiva), o Largo de Nossa Senhora de Lourdes, a Praça dos Namorados, a Praça Central, juntamente com a Igreja Matriz, dentre outros. Possuindo também, uma boa infraestrutura de apoio e de equipamentos, como é o caso de hotéis, pousadas e restaurantes. Segundo dados fornecidos por Guaratuba (2009), o município chegou a receber na temporada de 2008, 500.000 (quinhentos mil) turistas, basicamente em busca de sol e praia, hospedando-se na sua grande maioria, em segundas residências.

Com os atrativos acima enunciados pode-se perceber parte do potencial turístico do município, que se bem planejado, poderia tornar-se um pólo do turismo paranaense durante todos os meses do ano, através de outras modalidades de turismo, não apenas a de turismo de balneário. 
O ambiente litorâneo é na sua proporção terra, considerado humanamente seguro e privilegiadamente agradável, quando oferta a conjunção da terra, mar e do sol, se torna inegável a vocação dessas áreas para o turismo, especialmente para os indivíduos oriundos de áreas urbanizadas. Mas há um pesar em tudo isso, o turismo litorâneo, como o de montanha, por exemplo, é sazonal, ou seja, explorado de forma intensiva em poucos meses do ano.

Além disso, o turismo força o traço dos lugares, das regiões, das paisagens criando atrativos para o fluxo da sociedade revalorizando tais paisagens, colocando em movimento a construção real e simbólica dos territórios turísticos. (LUCHIARI, 2000). O problema da sazonalidade está na valorização estética das paisagens naturais e dos atrativos turísticos de uma forma geral, em um determinado período do ano.

$\mathrm{O}$ ideal antes de procurar analisar a sazonalidade e o que pode ser feito para reverter esta situação, é analisar a vocação turística do núcleo receptor e a caracterização e a classificação dos fluxos turísticos. Dentro da classificação de Beni (1998) sobre os fluxos turísticos, Guaratuba se enquadraria no fluxo turístico de estada fério-menso-estacional, ou seja, refere-se aos turistas que permanecem numa dada área receptora superior a uma semana, geralmente em suas férias de verão ou inverno. É relevante salientar que este tipo de fluxo mobiliza toda a oferta de bens e serviços apenas pelo período de tempo de suas férias, dificultando a possibilidade de alguns empreendimentos permanecerem abertos durante o ano todo, gerando um grande decréscimo na renda da população.

A sazonalidade é um problema constante no litoral do Paraná, percebe-se que cidades como Guaratuba, Matinhos e Pontal do Paraná, com belezas cênicas e clima agradável o ano todo, capazes de atrair pessoas das mais diversas localidades, têm dificuldade para planejar o turismo e procurar reverter o problema, principalmente econômico, da sazonalidade. Talvez isso possa acontecer por questões políticas, ou até mesmo falta de vontade da comunidade local em lutar pelo fomento do turismo fora da temporada. Através de observação assistemática (MARCONI e LAKATOS, 2008) percebe-se que há falta de incentivo e de motivação das pessoas em transformar o município em um local atrativo durante o ano todo.

Para Moraes (2004), deve haver uma tecnologia de urbanização coerente que possibilite o desenvolvimento econômico e também vise o uso sustentável dos recursos 
naturais, compatibilize o desfrute turístico do território e a preservação da paisagem natural e da cultura local. Os planejadores turísticos, de uma forma geral, deveriam lutar para que o governo fornecesse embasamento e diretrizes que guiassem o desenvolvimento do turismo de maneira a minimizar os impactos oriundos da sazonalidade.

$\mathrm{Na}$ realidade, a sazonalidade aqui abordada de forma parcial é um tema que deve ser trabalhado com mais profundidade, como forma de levantar dados para propor medidas que melhorem a qualidade de vidas das pessoas que residem em locais como Guaratuba. O problema econômico da sazonalidade poderia ser sanado através de políticas públicas que pudessem viabilizar a inserção de outros meios de produção no município. Outra forma de minimizar a sazonalidade seria a capacitação do município para promover e receber vários tipos de eventos e consequentemente mobilizar a população e os equipamentos de apoio durante vários períodos do ano.

Por ser um município de clima agradável, poderia haver um estímulo em atrair pessoas aposentadas para residirem no município, ou até mesmo frequentá-lo em outras épocas do ano, mas para isso há a necessidade de uma melhoria efetiva no que diz respeito ao sistema médico-hospitalar e de segurança.

Assim, de acordo com o comentado acima, identifica-se que Guaratuba possui algumas alternativas para reverter alguns problemas criados pela sazonalidade, mas isso somente acontecerá a partir de um planejamento mais amplo e adequado em consonância com o poder público, privado e comunidade local.

\section{CONSIDERAÇÕES FINAIS}

Através do que foi exposto anteriormente percebe-se a importância do turismo para a comunidade de Guaratuba e a necessidade de um planejamento mais abrangente para que os impactos negativos da sazonalidade sejam revertidos de forma a melhorar a qualidade de vida das pessoas residentes no município.

Não se pode ignorar que planejar o turismo é uma atividade complexa e requer profissionais realmente qualificados e que traduzam sustentavelmente a sua ideologia frente à necessidade de estruturar o turismo para que seu retorno seja válido para todos os envolvidos. 
Estudar a sazonalidade exige pesquisas mais aprofundadas embasando-se em dados econômicos, culturais e principalmente sociais. Este artigo é uma reflexão inicial frente a complexidade do estudo da sazonalidade do município em questão. O turismo é um processo intenso, onde todos os elementos se encontram em constante movimento e mostram mudanças e particularidades. Estudar este fenômeno requer interdisciplinaridade e valorização da comunidade onde ele está inserido. O saber turístico requer conhecimento de todo o território, exigindo questionamentos de todos os elementos que o envolvem. Essa característica metodológica da realidade turística está muito ligada à geografia, pois possibilita uma investigação epistemológica mais aprofundada dos seus fenômenos.

O turismo nacional está em alta, municípios costeiros, como é o caso de Guaratuba merecem um tratamento mais qualificado para crescerem e poderem oferecer o que têm de melhor aos turistas, e ao mesmo tempo dignificar a vida de suas comunidades locais. Tem-se, portanto, uma excepcional oportunidade para se desenvolver, valorizar e incrementar a atividade nos municípios litorâneos, buscando garantir uma melhor qualidade de vida às pessoas diretamente envolvidas com o turismo.

\section{REFERÊNCIAS}

ACKOFF, R. L. Planejamento empresarial. Trad. Marco Túlio de Freitas. São Paulo: LTC, 1975.

BAHL, M. Viagens e roteiros turísticos. Curitiba: Protexto, 2004.

BALL, R. M. Some aspects of tourism, seasonality and local labour markets. Area, UK, v. 21, n. 1, mar. de 1989. Blackwell Publising. Disponível em: <http://www.jstor.org/stable/i20002666>. Acesso em: 05/09/2011.

BARRETTO, M. Planejamento e organização do turismo. 4. ed. Campinas: Papirus, 1991.

BENI, M. C. Análise estrutural do turismo. São Paulo: Senac, 1998.

BOULLÓN, R. Planificación del espacio turístico. 3. ed. México: Trillas, 1997. 
BUTLER, R. Seasonality in tourism: Issues and problems. In: SEATON, A.V. (ed.), Tourism: the state of the art. Chichester, UK: John Wiley and Sons, p. 332-339, 1994.

CONSELHO DO LITORAL. Plano Diretor de Desenvolvimento Integrado Guaratuba (PDDI). Curitiba: Governo do Estado do Paraná, 2002.

CRUZ, R. de C. A. da. Introdução à geografia do turismo. São Paulo: Roca, 2001.

DENCKER, A. de F. M. Métodos e técnicas de pesquisa em turismo. 3. ed. São Paulo: Futura, 1998.

DOWBOR, L. A intervenção dos governos locais no processo de desenvolvimento. In: BAVA, S. C. (org.), Desenvolvimento local: geração de emprego e renda. São Paulo: Pólis, n. 2, p. 29-44, 1996.

DROULERS, M.; MILANI, C. R. S. Desenvolvimento local e turismo em Tarrafal Cabo Verde. Paris: UNESCO, 2002.

GUARATUBA, Prefeitura Municipal. 2009. Disponível em: <http://www.guaratuba.pr.gov.br/site/index.php>. Acesso em: 12/12/2009.

INSTITUTO BRASILEIRO DE GEOGRAFIA E ESTATÍSTICA (IBGE). Domicílios e população, Censo 2010. Disponível em: <http://www.ibge.gov.br/home/estatistica/populacao/censo2010/resultados_dou/PR2010 .pdf>. Acesso em: 09/09/2011.

INSTITUTO PARANAENSE DE DESENVOLVIMENTO ECONÔMICO E SOCIAL (IPARDES). Caderno Estatístico do Município de Guaratuba, 2009. Disponível em: <http://www.ipardes.gov.br/index.php>. Acesso em: 10/05/2010.

KRIPPENDORF, J. Sociologia do turismo: para uma nova compreensão do lazer e das viagens. Rio de Janeiro: Civilização Brasileira, 1989.

LUCHIARI, M. T. D. P. O lugar no mundo contemporâneo: turismo e urbanização em Ubatuba - SP. 222f. Tese (Doutorado) IFCH-Campinas, Campinas, 1999,

Turismo e meio ambiente na mitificação dos lugares. Turismo em Análise, ECA/Escola de Comunicações e Artes da USP, São Paulo, v. 11, n.1, p. 35-43, mai., 2000.

MAMBERTI, M, M, S.; BRAGA, R. Arranjos produtivos turísticos e desenvolvimento local. In: SEMINÁRIO INTERNACIONAL O DESENVOLVIMENTO LOCAL NA INTEGRAÇÃO: ESTRATÉGIAS, INSTITUIÇÕES E POLÍTICAS, 1, 2004, Rio Claro. Anais... Rio Claro: Unesp, 2004. p. 1-13. Disponível em: <http://www.rc.unesp.br/igce/planejamento/publicacoes/TextosPDF/mamberti01.pdf > Acesso em: 20/07/2008. 
MARCONI, M. de A.; LAKATOS, E. M. Técnicas de pesquisa. 7. ed. São Paulo: Atlas, 2008.

MORAES, S. T. Considerações sobre a produção do espaço turístico na contemporaneidade. Turismo - Visão e Ação, v. 6, n. 3, p. 277-293, set./dez. 2004.

MOTA, K. C. N. Marketing turístico: promovendo uma atividade sazonal. São Paulo: Atlas, 2001.

OLIVEIRA, A. P. Turismo e desenvolvimento. 5. ed. São Paulo: Atlas, 2005.

OMT. Introdução ao turismo. Trad. Dolores Martin Rodriguez Corner. São Paulo: Roca. 2001.

PETROCCHI, M. Turismo: planejamento e gestão. 2. ed. São Paulo: Futura, 1998.

PORTUGUEZ, A. P. Agroturismo e desenvolvimento regional. São Paulo: Hucitec, 2002.

RUSCHMANN, D. Marketing turístico: um enfoque promocional. 2. ed. Campinas: Papirus, 1995.

SANTOS, M. Por uma Geografia Nova: da crítica da Geografia a uma Geografia Crítica. São Paulo: Editora da Universidade de São Paulo, 2004.

SILVEIRA, M. A. T. da. Turismo, políticas de ordenamento territorial e desenvolvimento. Um foco no estado do Paraná no contexto regional. $277 \mathrm{f}$. Tese (Doutorado em Geografia) Faculdade de Filosofia, Letras, Ciências Humanas, Universidade de São Paulo - USP, São Paulo, 2002.

XAVIER, H. Turismo e desenvolvimento local: a percepção geográfica dos lugares. In: ENCUENTRO DE GEOGRAFOS DE AMERICA LATINA, 8, 2001, Santiago, Chile. Anais... Santiago, Universidade de Chile, 2001. Publicação em CR-ROM. Disponível em: <http://herbe.br.tripod.com/index2.htm>. Acesso em: 11/05/ 2008.

Recebido em: 08-05-2011.

Aprovado em: 08-06-2011. 